\title{
Pengaruh Ekstrak Etanol Daun Murbei (Morus Alba L.) dengan Glibenklamid Terhadap Ekspresi Gen CYP3A4 pada Kultur Sel Hepg2
}

\section{Effect of Ethanol Extract Of Murbei Leaves (Morus Alba L.) with Glibenclamide on CYP3A4 Gene Expression in Hepg2 Cell Culture}

\author{
Nuralih $^{1,2}$, Churiyah ${ }^{2}$, Sabar Pambudi ${ }^{2}$, Swasono R. Tamat ${ }^{1}$, Okpri Meila ${ }^{3}$ \\ ${ }^{1}$ Fakultas Farmasi, Universitas Pancasila, Jl. Raya Lenteng Agung No.56-80, RT.1/RW.3, Srengseng Sawah, \\ Kec. Jagakarsa, Jakarta \\ ${ }^{2}$ Teknologi Farmasi dan Medika, BPPT Puspiptek Serpong \\ ${ }^{3}$ Fakultas Farmasi Institut Sains dan Teknologi Nasional Jl.Moh Kahfi II Srengseng Sawah Jagakarsa Jakarta \\ Selatan \\ Email: nuralih79@gmail.com; okprimeila@gmail.com
}

\begin{abstract}
Abstrak
Daun murbei merupakan ramuan tradisional dan diprediksi memiliki ecdysteronecompound yang berperan sebagai antihyperglicemid. Glybenclamide adalah obat sintetis yang digunakan untuk menyembuhkan penyakit diabetes mellitus 2. Daun dilaporkan sebagai penghambat kompetitif enzim CYP3A4, yang metabolizingglibenclamide. Namun, dalam banyak kasus, kombinasi ramuan dengan obat sintesis menyebabkan interaksi jika digunakan pada saat bersamaan. Penelitian ini bertujuan untuk mengetahui interaksi ekstrak daun murbei etanol dengan glibenclamide melalui ekspresi gen CYP3A4 pada kultur sel HepG2. Sampel ekstrak murbei, glibenklamid, dan kombinasi kedua sampel diuji ke dalam kultur sel HepG2. Kemudian RNA diisolasi dan dimurnikan menggunakan PCR real time untuk melihat gen ekspresi CYP3A4. Akibatnya, ekstrak murbei bertindak sebagai enzim penghambat CYP3A4, sedangkan glibenklamid adalah enzim substrat. Kombinasi murbei dan glibenklamida menunjukkan peningkatan ekspresi gen CYP3A4, berarti enzim yang lebih besar diproduksi, dan obat yang lebih rendah pada plasma darah.
\end{abstract}

Kata kunci: Diabetes mellitus, ekspresi gen CYP3A4, HepG2, murbei.

\begin{abstract}
Mulberry leaf is a traditional herb and predicted has ecdysteronecompound which act as antihyperglicemid. Glybenclamide is a synthetic medicine used to cure diabetes mellitus type 2. The leaf reported as competitive inhibitor of CYP3A4 enzyme, which metabolizingglibenclamide. However, in many cases, combination of herbs with synthesis drugs causes interaction if used at the same time. This research aimed to see interaction of ethanol mulberry leaf extract with glibenclamide through CYP3A4 gene expression in HepG2 cell culture. Sample of mulberry extract, glibenclamide, and combination both sample were tested into cell HepG2 culture. Then RNA were isolated and purification using real time PCR to see the gene CYP3A4 expression. As a result, mulberry extract acts as inhibitor enzyme CYP3A4, while glibenclamide is enzyme substrate.The combination of mulberry and glibenclamide showed increased of expression of CYP3A4 gene, means greater enzyme produced, and lower medicine on blood plasma.
\end{abstract}

Keywords:Diabetes mellitus, gene expression CYP3A4, glibenclamide, HepG2, mulberry.

\section{PENDAHULUAN}

Interaksi obat terjadi jika efek suatu obat berubah akibat adanya obat lain, makanan, atau minuman. Interaksi obat dapat menghasilkan efek yang memang dikehendaki, atau efek yang tidak dikehendaki seperti menyebabkan efek samping obat atau toksisitas karena meningkatnya kadar obat di dalam plasma, atau sebaliknya menurunnya kadar obat 
dalam plasma yang menyebabkan hasil terapi menjadi tidak optimal (Ament et. al, 2000).

Mekanisme interaksi obat dapat melalui beberapa cara, yakni interaksi secara farmasetik (inkompatibilitas), farmakokinetik, dan farmakodinamik. Interaksi farmakokinetik meliputi absorpsi, distribusi, metabolisme dan ekskresi dapat meningkatkan ataupun menurunkan kadar obat di dalam plasma obat. Mekanisme interaksi yang terjadi pada proses metabolisme obat dapat berupa penghambatan metabolisme, induksi metabolisme, dan perubahan aliran darah hepatik. Hambatan ataupun induksi enzim pada proses metabolisme obat terutama berlaku terhadap obat-obat atau zat-zat yang merupakan substrat enzim mikrosom hati sitokrom P450 (CYP), diantaranya CYP3A yang memetabolisme lebih dari $50 \%$ obatobatan (Gitawati, 2008).

Dalam skala in vitro, enzim CYP3A4 dapat diproduksi melalui Sel HepG2. Sel HepG2 merupakan sel line hepatokarsinom yang telah sukses dikultivasi. Sel ini memiliki tingkat diferensiasi morfologi dan fungsional yang tinggi, serta lebih stabil dan seragam dibandingkan sel hati primer, sehingga cocok sebagai model untuk mempelajari dinamika protein pada manusia secara in vitro (Adam, et al., 2012).

Daun Murbei (Morus alba L.) telah digunakan sebagai obat tradisional antidiabetes karena berkhasiat menekan hiperglikemia. Penggunaan daun murbei sebagai obat tradisional dimanfaatkan dengan cara meminum air hasil seduhan atau rebusan dari daun tersebut. Daun murbei mengandung 1-deoxynorijimycin (DNJ), flavonol glikosida, tanin, steroid, saponin, dan senyawa kimia lainnya. DNJ pada murbei akan menghambat aktivitas enzim aglucosidase usus halus (Amma, 2009, Wang et al., 2013).

Glibenklamid merupakan obat diabetes melitus tipe 2, yang termasuk dalam golongan sulfonilurea yang merupakan sekretagok insulin, dan telah secara luas digunakan baik sebagai mono terapi ataupun kombinasi karena kemampuannya dalam mengontrol glukosa darah secara efisien (Katzung, 2002). Selain itu sulfonilurea sering diberikan sebagai terapi kombinasi karena memiliki kemampuan untuk meningkatkan atau mempertahankan sekresi insulin dengan merangsang sel beta pankreas untuk melepaskan insulin (American Diabetes Association, 2012).

Ekstrak daun murbei telah dilaporkan dapat menurunkan kadar glukosa darah pada pengujian antidiabetes secara in vivo (Amit et al.), tetapi belum diketahui pengaruhnya terhadap ekspresi CYP3A4. Sedangkan glibenklamid sebagai obat antidiabetes oral telah diketahui sebagai substrat enzim CYP3A4. Oleh Karena itu penelitian ini bertujuan mengamati ekspresi gen CYP3A4 pada kutur HepG2 dengan perlakuan ekstrak daun murbei dan glibenklamid secara tunggal atau kombinasi dari keduanya.

\section{METODE PENELITIAN \\ Bahan}

Bahan utama yang digunakan dalam penenlitian adalah ekstrak etanol daun murbei (Morus alba L.) yang berasal dari Taman Nasional Gunung Rinjani Lombok NTB, dan sel HepG2 dari laboratorium Pusat Teknologi Farmasi dan Medika (PTFM) BPPT. Bahan lain adalah glibenklamid serbuk produk Tokyo Chemical Industry Co., Ltd, Dulbecco minimal essential medium (DMEM) dan foetal bovine serum (FBS) dari Gibco Ltd (Singapura), dimetil sulfoksida (DMSO) dari Sigma-Aldrich Ltd (Singapura), Trizole isolation reagent (Invitrogen, Karlsuhe, Germany), isopropil alkohol (MP Biomedical), air bebas RNAse (Promega Corporation, Singapura), primer $\beta$ actin dan CYP3A4 ( $1^{\text {st }}$ Base Ltd, Singapura), kit one-step qRT-PCR KAPA SYBR Fast Bio-Rad (Bio-Rad Laboratories Inc, Singapura). 


\section{Alat}

Alat-alat yang digunakan meliputi alatalat gelas, evaporator, karl-fischerlaminair flow cabinet, mikropipet merek eppendorp, tip, mikrotube, autoclave, inkubator $\mathrm{CO}_{2}$ merek memmert, spektrofotometer merek biodrop, centrifuge, PCR konvensional alat Real Time RT-PCR merek biorad.

\section{Pembuatan ekstrak etanol daun murbei}

Serbuk simplisia kering sebanyak $1 \mathrm{~kg}$ diekstraksi dengan cara dingin, yaitu maserasi dengan pengadukan selama empat jam menggunakan pelarut etanol $70 \%$ setinggi $3-5 \mathrm{~cm}$ diatas serbuk simplisia. Kemudian, maserat pertama disaring dan dilakukan remaserasi sebanyak tiga kali, sehingga dihasilkan ekstrak cair yang sudah tidak berwarna pekat.

\section{Kultur sel HepG2}

Sel HepG2 yang dikulturkan dalam medium DMEM HG dengan 10\% FBS dan $1 \%$ antibiotik pen-strep pada suhu $37^{\circ} \mathrm{C}$ dengan kelembaban $\mathrm{CO}_{2} 5 \%$. Kemudian sel ditempatkan ke dalam 12 well plate dengan kerapatan sel $2,0 \times 10^{5} \mathrm{sel} / \mathrm{ml}$ media. Kultur sel diinkubasi satu hari sebelum diberikan obat yang diujikan (Sambrook and Russel, 2001).

\section{Uji sitoksisitas}

Selanjutnya, uji sitotoksik dilakukan terhadap bahan uji untuk mengetahui konsentrasi $50 \%$ efek tosksik terhadap partumbuhan sel HepG2, nilai $\mathrm{IC}_{50}$ bahan serta sebagai rujukan konsentrasi pada uji sampel. Metode yang digunakan adalah metode MTT yang menghitung jumlah sel hidup setelah diberikan ekstrak (Gerets et al., 2012).

\section{Pengujian sampel}

Sampel uji berupa ekstrak etanol daun murbei, glibenklamid, dan kombinasi ekstrak etanol daun murbei dan glibenklamid. Setiap sample dilarutkan ke dalam DMSO $\leq 0,1 \%$, kemudian diujikan ke kultur sel HepG2 yang telah diinkubasi selama satu hari dengan konsentrasi. Pengujian sampel dilakukan pada kondisi $37^{\circ} \mathrm{C}$ dengan $\mathrm{CO}_{2} 5 \%$ selama 2 hari (48 jam). Pemanenan kultur sel menggunakan Trizole isolation reagent dan perhitungan konsentrasi total RNA dengan spektrofotometer pada absorbansi $260 \mathrm{~nm}-$ $280 \mathrm{~nm}$. Pengujian sampel dilakukan sebanyak 3 kali pengulangan.

\section{Isolasi RNA}

Isolasi RNA dilakukan pada kultur sel HepG2 yang telah diuji menggunakan tripsin-EDTA dan total RNA diekstraksi menggunakan reagen Tripure isolation sesuai dengan petunjuk dari manufaktur.

\section{Pengukuran kemurnian RNA}

RNA yang telah diisolasi kemudian dimurnikan dengan spektrofotometer pada panjang gelombang $260 \mathrm{~nm}$. Kemurnian RNA dipastikan dengan perhitungan absorbansi pada $260 \mathrm{~nm}-280 \mathrm{~nm}$.

\section{Real Time RT-PCR}

Pada tahap selanjutnya, preparasi sampel dilakukan dengan mencampurkan $30 \mathrm{mM}$ tiap primer, $12,5 \mu \mathrm{L}$ SYBR green RT PCR reaction mix, $0,5 \mu \mathrm{L}$ iScript reverse transcriptase, $100 \mu \mathrm{g}$ template RNA, dan 9,5 $\mathrm{L}$ air bebas RNAse. Sampel diinkubasi dalam sistem real-time thermal detection dengan kondisi: 10 menit suhu $50^{\circ} \mathrm{C}$ untuk sintesis cDNA, 5 menit pada suhu $95^{\circ} \mathrm{C}$ untuk inaktivasi iScript reverse transcriptase, dan siklus PCR dan deteksi (40 siklus) dengan pengaturan 10 detik pada suhu $95^{\circ} \mathrm{C}$ untuk proses denaturasi, 30 detik pada suhu $58^{\circ} \mathrm{C}$ untuk proses annealing dan ekstensi. Nilai ambang batas $(\mathrm{Ct})$ dihitung secara otomatis oleh software. Data nilai ambang batas $(\mathrm{Ct})$ diolah sesuai dengan metode yang dijelaskan oleh Pfaffl.

\section{Ekspresi gen CYP3A4}

Ekspresi gen CYP3A4 diketahui dengan melihat nilai ambang $(\mathrm{Ct})$ dari setiap perlakuan menggunakan metode Pfaffl (Matsuda et al., 2002).

\section{HASIL DAN PEMBAHASAN}

Hasil uji sitotoksisitas dari ekstrak etanol daun murbei dan glibenklamid terhadap sel HepG2 ditunjukkan pada gambar 1. 
Berdasarkan analisa menggunakan software GraphPad Versi5 diperoleh nilai $\mathrm{IC}_{50}$ untuk ekstrak etanol sebesar 441.6 ppm sedangkan glibenklamid memiliki $\mathrm{IC}_{50}$ sebesar 201.4 ppm.

Uji Sitotoksisitas

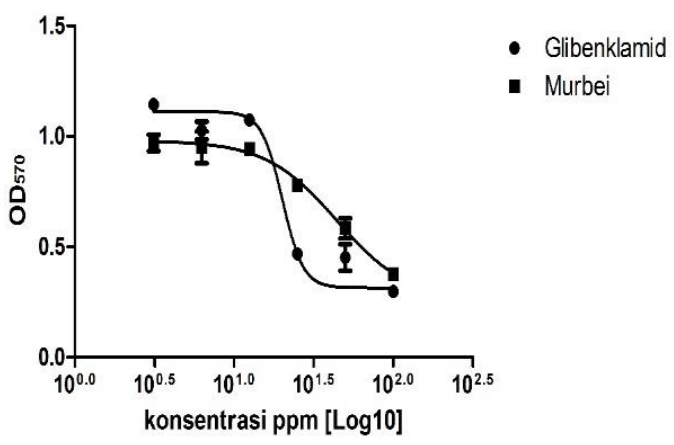

Gambar 1. Hasil uji sitoksisitas

Hasil $\mathrm{IC}_{50}$ dari ekstrak murbei dan glibenklamid pada uji sitotoksisitas bertujuan mengetahui pengaruh ekstrak murbei dan glibenklamid maupun kombinasi ekstrak daun murbei dan glibenklamid dengan perbandingan 1:1 terhadap ekspresi CYP3A4 digunakan konsentrasi masing-masing sampel uji 6.25, 12.5, 25, 50 dan $100 \mathrm{ppm}$. Pengujian dilakukan sebanyak 3 kali ulangan, meggunakan 24 well plate dengan jumlah sel/well 2 x 105 sel.

Pada pengujian Real-Time PCR dilakukan perancangan primer yang tepat, karena primer menjadi faktor penting dalam amplifikasi yang menentukan berhasil atau tidaknya proses Real-Time PCR. Selain itu, perancangan primer yang tepat diperlukan untuk meminimalisasi amplifikasi sekuens yang tidak diinginkan. Perancangan primer yang tepat akan menghasilkan primer dengan spesifitas tinggi.

Primer yang digunakan dalam penelitian isolasi RNA menggunakan Trizole isolation reagent yang mengandung fenol dan guanidin isotiosianat, dimana keduanya berfungsi menjaga RNA agar tetap utuh ketika terjadi pelisisan sel. Selain itu, guanidin isotiosianat juga berfungsi untuk mendenaturasi protein seperti enzim RNAse dan protein kontaminan lainnya. Kemudian, inkubasi diperlukan untuk memaksimalkan kerja dari fenol dan guanidin isotiosianat. Setelah diinkubasi, penambahan kloroform dilakukan untuk memisahkan antara kontaminan seperti lipid dan protein dengan RNA. Penambahan kloroform diikuti dengan sentrifugasi sehingga terbentuk dua fase, yaitu (a) fase air (berisi RNA) dan fase organik berisi protein yang larut dalam fenol dan lipid yang larut dalam kloroform. Sentrifugasi dilakukan pada suhu $4^{\circ} \mathrm{C}$ untuk meminimalisasi degradasi RNA akibat panas yang terjadi saat sentrifugasi.

Selanjutnya, fase air dipindahkan ke dalam microtube baru dan ditambahkan isopropanol. Penambahan isopropanol dimaksudkan untuk pemulihan RNA dengan cara pengendapan dan terbentuk pelet RNA. Setelah itu sentrifugasi dilakukan untuk mengendapkan RNA sehingga pelet RNA terlihat di dasar atau dinding microtube. Kemudian supernatan dibuang dan ditambahkan etanol. Fungsi etanol sama dengan isopropanol, yaitu untuk mengendapkan RNA. Penggunaan isopropanol lebih baik dari etanol dalam mengendapkan RNA. Namun isopropanol kurang volatil, sehingga dilakukan kombinasi penambahan isopropanol dan etanol untuk mendapatkan pellet RNA dengan kemurnian tinggi. Selanjutnya, pelet RNA dialiri dengan udara kering untuk menghilangkan sisa etanol. Setelah selesai proses pengeringan, pelet RNA diresuspensi dengan RNAse Free Water. Kemudian dilakukan pengukuran konsentrasi dan kemurnian RNA dengan spektrofotometer pada panjang gelombang $260 \mathrm{~nm}$ dan 280 $\mathrm{nm}$. Pada panjang gelombang $260 \mathrm{~nm}$ menunjukkan konsentrasi total asam nukleat, sementara pada panjang gelombang $280 \mathrm{~nm}$ menunjukkan kemurnian RNA. Data hasil pengukuran konsentrasi dan kemurnian RNA CYP3A4 dapat dilihat pada tabel 1.

Konsentrasi RNA hasil isolasi yang diperoleh antara 163,4 ng hingga 3176,8 ng. 
Selanjutnya, RNA hasil isolasi disimpan pada $-80^{\circ} \mathrm{C}$ untuk menghindari kontaminasi dengan RNAse serta degradasi RNA akibat suhu.

Tabel 1. Data konsentrasi dan kemurnian RNA ekstrak etanol murbei (M), glibenklamid (G) dan kombinasi ekstrak murbei dan glibenklamid (K) dengan kontrol $(\mathbf{C})$.

\begin{tabular}{ccccc}
\hline \multirow{2}{*}{ No } & \multirow{2}{*}{ KodeSampel } & \multicolumn{3}{c}{ Konsentrasi RNA $(\mathrm{ng} / \mu \mathrm{l})$} \\
\cline { 3 - 5 } & & 1 & 2 & 3 \\
\hline 1 & $\mathrm{C}$ & 163,4 & 489,5 & 593,7 \\
2 & $\mathrm{G}_{1}$ & 212,7 & 714,2 & 270,1 \\
3 & $\mathrm{G}_{2}$ & 238,9 & 198,4 & 705,3 \\
4 & $\mathrm{G}_{3}$ & 406,2 & 414,8 & 433,5 \\
5 & $\mathrm{G}_{4}$ & 993,2 & 185,9 & 1534,3 \\
6 & $\mathrm{G}_{5}$ & 826,9 & 1065,4 & 1089,5 \\
7 & $\mathrm{M}_{1}$ & 300,3 & 277,8 & 217,7 \\
8 & $\mathrm{M}_{2}$ & 363,2 & 447,8 & 415,1 \\
9 & $\mathrm{M}_{3}$ & 869,5 & 781,4 & 1295,1 \\
10 & $\mathrm{M}_{4}$ & 3176,8 & 1420,6 & 432,7 \\
11 & $\mathrm{M}_{5}$ & 474,5 & 629,8 & 890,3 \\
12 & $\mathrm{~K}_{1}$ & 105,2 & 257,7 & 444,9 \\
13 & $\mathrm{~K}_{2}$ & 753 & 307,4 & 643,9 \\
14 & $\mathrm{~K}_{3}$ & 639,1 & 74,57 & 492,1 \\
15 & $\mathrm{~K}_{4}$ & 159,5 & 373,2 & 967,1 \\
16 & $\mathrm{~K}_{5}$ & 657,4 & 519,3 & 386,2 \\
\hline
\end{tabular}

Ini adalah primer gen CYP3A4 dengan primer gen $\beta$-actin. Primer CYP3A4 forward memiliki urutan basa 5CTCAAGGAGATGGTCCCTATCATTGC3 dan CYP3A4 reverse 5TAGGCCCCAAAGACGTCTTTCAAGG-3. Sedangkan primer $\beta$-actin memiliki urutan basa 5-CTGGCACCCAGCACAATG-3 dan primer $\quad \beta$-actin $\quad$ reverse 5 GCCGATCCACACGGAGTACT-3. Urutan basa primer CYP3A4 dan $\beta$-actin diuji spesifitasnya dengan menggunakan software Snapgene. Hasil uji spesifitas menunjukkan urutan basa primer CYP3A4 dan $\beta$-actin memiliki kemiripan $100 \%$ dengan CYP3A4 dan $\beta$-actin manusia.

Untuk menguji efisiensi amplifikasi gen CYP3A4 menggunakan primer yang sudah didisain sebelumnya dilakukan optimasi suhu annealing primer dengan menggunakan PCR konvensional. Suhu annealing yang digunakan dalam optimasi adalah $55^{\circ} \mathrm{C}$ dan $60^{\circ} \mathrm{C}$. Ukuran fragmen hasil amplifiksi dengan menggunakan primer yang telah didesain adalah sekitar 76 bp. Berdasarkan hasil optimasi suhu annealing yang paling optimal untuk mengamplifikasi gen target adalah suhu $60^{\circ} \mathrm{C}$.

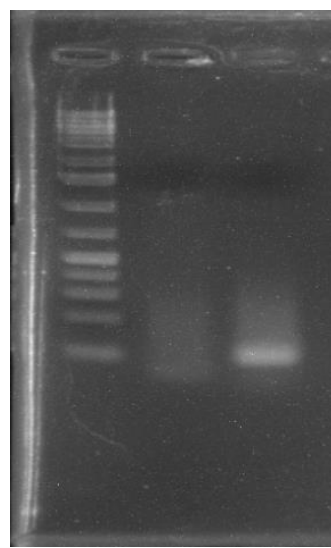

Keterangan :

1. Marker $1 \mathrm{~kb}$ ladder plus

2. Amplifikasi CYP3A4 suhu $55^{\circ} \mathrm{C}$

3. Amplifikasi CYP3A4 suhu $60^{\circ} \mathrm{C}$

\section{Gambar 2. Elektroforesis optimasi PCR konvensional gen CYP3A4}

Hasil amplifiksi pada suhu $55^{\circ} \mathrm{C}$ menunjukan hasil smear yang diakibatkan oleh penempelan primer pada posisi yang tidak spesifik pada template cDNA (gambar 2 lajur 2). Oleh sebab itu peningkatan suhu annealing diharapkan dapat membuat primer menempel pada gen target seperti yang ditunjukan pada gambar 2 pada lajur 3. Dari hasil optimasi PCR konvensional diperoleh suhu optimal yang akan digunakan dalam Real Time PCR dengan primer CYP3A4 adalah suhu $60^{\circ} \mathrm{C}$ (gambar 3 ).

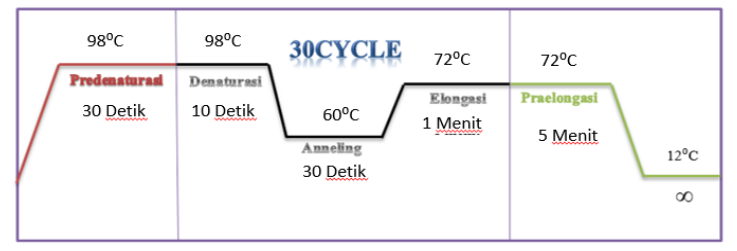

Gambar 3. Hasil optimasi PCR konvesional

Proses Real-Time PCR dilakukan dengan menggunakan KAPA SYBR master mix yang memiliki komposisi enzim Hot start KAPA SYBR DNA Polymerase, SYBR Green I fluorescent dye, $\mathrm{MgCl}_{2}$, dNTP , dan 
stabilizer. Penggunaan Real-Time PCR master mix memiliki keuntungan berupa kemudahan dalam penggunaannya serta ketepatan jumlah komponen yang diperlukan dalam reaksi Real-Time PCR. Prosedur Real-Time dilakukan dengan jumlah siklus 35. Didasari pada hasil optimasi yang telah dilakukan sebelumnya yang menunjukan bahwa siklus yang optimal adalah 35 (Gambar 4).

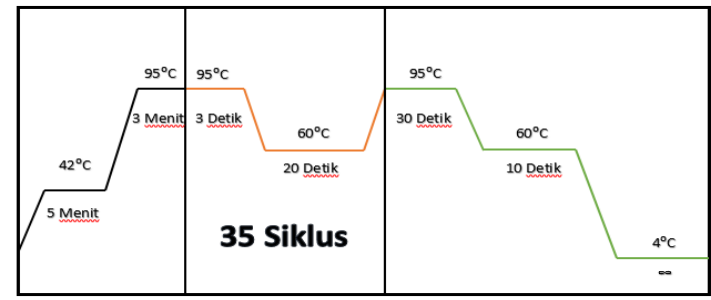

Gambar 4. Hasil optimasi Real Time PCR

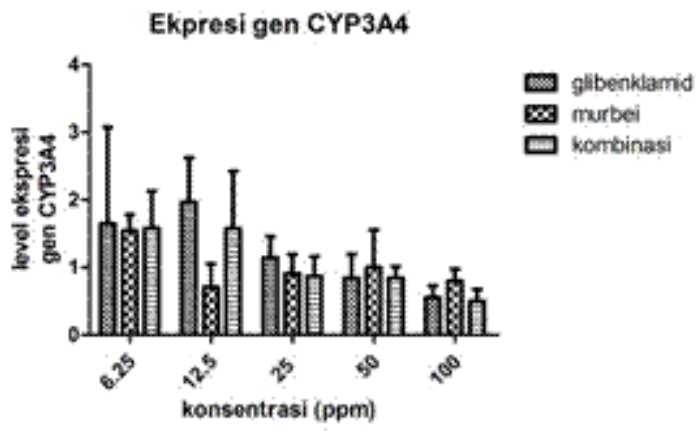

Gambar 5. Ekspresi gen CYP3A4

Berdasarkan analisa ekspresi CYP3A4 secara Real Time PCR pada Gambar 5 perlakuan ekstrak murbei menunjukkan bahwa semakin tinggi konsentrasi yang diberikan ekspresi CYP3A4 semakin menurun, dengan demikian diduga bahwa murbei merupakan inhibitor enzim CYP3A4. Demikian pula dengan perlakuan glibenklamid semakin tinggi konsentrasi Glibenklamid ekspresi CYP3A4 juga semakin menurun. Hal yang sama pada kombinasi keduanya, yaitu ekspresi CYP3A4 juga semakin kecil dengan meningkatnya konsentrasi uji yang diberikan.
Nilai rasio ekpresi CYP3A4 pada perlakuan ekstrak daun murbei dan glibenklamid tercantum pada Tabel 2 dimana pada perlakuan ekstrak daun murbei menunjukkan peningkatan rasio ekspresi gen CYP3A4 sebesar 1.43 dan 1.19 kali dibandingkan glibenklamid pada dosis 100 ppm dan 50 ppm. Sebaliknya pada konsentrasi yang lebih rendah 25, 12,5 dan 6,25 ppm rasio ekspresi CYP3A4 akibat perlakuan murbei lebih rendah dibanding glibenklamid.

Tabel 2. Nilai rasio ekspresi CYP3A4 pada perlakuan ekstrak daun murbei dan glibenklamid

\begin{tabular}{cccc}
\hline $\begin{array}{c}\text { Konsen } \\
\text { trasi }\end{array}$ & $\begin{array}{c}\text { Mur } \\
\text { bei }\end{array}$ & $\begin{array}{c}\text { Gliben } \\
\text { klamid }\end{array}$ & $\begin{array}{c}\text { Nilai Rasio } \\
\text { Ekspresi }\end{array}$ \\
\hline 100 & 0.8 & 0.56 & 1.43 \\
50 & 1 & 0.84 & 1.19 \\
25 & 0.91 & 1.14 & 0.80 \\
12.5 & 0.71 & 1.97 & 0.36 \\
6.25 & 1.54 & 1.64 & 0.94 \\
\hline
\end{tabular}

Tabel 3. Nilai rasio ekpresi CYP3A4 pada perlakuan ekstrak murbei dan kombinasi ekstrak murbei dari glibenklamid (1:1)

\begin{tabular}{cccc}
\hline $\begin{array}{c}\text { Konsent } \\
\text { rasi }\end{array}$ & $\begin{array}{c}\text { Mur } \\
\text { bei }\end{array}$ & $\begin{array}{c}\text { Kombi } \\
\text { nasi }\end{array}$ & $\begin{array}{c}\text { Nilai Rasio } \\
\text { Ekspresi }\end{array}$ \\
\hline 100 & 0.8 & 0.5 & 1.60 \\
50 & 1 & 0.85 & 1.18 \\
25 & 0.91 & 0.87 & 1.05 \\
12.5 & 0.71 & 1.57 & 0.45 \\
6.25 & 0.54 & 1.58 & 0.34 \\
\hline
\end{tabular}

Sedangkan rasio ekspresi CYP3A4 antara ekstrak daun murbei dengan kombinasi pada Tabel 3menunjukkan peningkatan ekspresi gen CYP3A4 pada ekstrak daun murbei sebesar 1.60, 1.18 dan 1.05 kali dibandingkan kombinasi ekstrak daun murbei dan glibenklamid pada dosis 100 ppm, 50 ppm dan 25 ppm. Sebaliknya pada konsentrasi dibawahnya 12,5 dan $6,25 \mathrm{ppm}$ rasio ekspresi perlakuan murbei menjadi lebih kecil yaitu 0,45 dan 0,34\% 
dibanding dengan kombinasi murbei dan glibenklamid.

Semakin tinggi eskpresi CYP3A4 berarti semakin banyak enzim yang diproduksi dan aktivitas metabolisme oleh enzim tersebut semakin meningkat sehingga kadar obat didalam plasma semakin sedikit. Sebaliknya semakin rendah ekspresi CYP3A4 semakin sedikit kadar enzim dan metabolisme menurun sehingga kadar obat didalam plasma menjadi lebih banyak.

Interaksi antara ekstrak daun murbei sebagai inhibitor CYP3A4 dengan glibenklamid sebagai substratnya akan menyebabkan peningkatan kadar plasma atau peningkatan bioavailabilitas glibenklamid sehingga memungkinkan aktivitas glibenklamid yang meningkat sampai terjadinya efek samping yang tidak dikehendaki yaitu peningkatan efek hipoglikemik yang membahayakan.
Dengan demikian pemberian ekstrak daun murbei pada pasien diabetes melitus yang menerima glibenklamid, dosis pemberian glibenklamid dapat diturunkan sehingga efek sampingnya dapat diminimalkan.

\section{KESIMPULAN}

Pemberian secara tunggal ekstrak murbei akan menghambat enzim CYP3A4, sedangkan glibenklamid merupakan substrat enzim CYP3A4. Pengamatan ekspresi CYP3A4 antara ekstrak daun murbei dengan kombinasi menunjukkan peningkatan ekspresi gen CYP3A4. Hal tersebut menandakan semakin banyak enzim yang diproduksi dan aktivitas metabolisme oleh enzim tersebut semakin meningkat sehingga kadar obat di dalam plasma semakin sedikit.

\section{DAFTAR PUSTAKA}

Adam I, Melva L, Arleni, SriWAJ, Franciscus DS. Influence of primaquine and ritonavir interaction on CYP3A4 mRNA expression in HepG2 cell culture. Medical Journal Indonesia. 2012; 2(1):3-7.

Ament PW, Bertolino JG, Liszewski JL. Clinical pharmacology: clinically significant drug interactions. Am Fam Physician. 2000; 61:1745-1754.

American Diabetes Association. Standards of medical care in diabetes. Diabetes care. 2012:11 - 13 .

Amit K, Pulok KM, Sankarsan S, Shiv B, SK Milan A and Subrata P. Possible herb-drug interaction of Morus alba L. $\alpha$ potential anti-diabetic plant from Indian Traditional Medicine. Indian Journal of Traditional Knowledge. 2015; 14(4): 626-631.

Amma NR. 2009. Efek hipoglikemik ekstrak daun murbei (Morusmulticaulis) terhadap kadar glukosa darah tikus dm. Tesis. Sekolah Pasca sarjana Institut Pertanian Bogor.

Gerets HHJ, Tilmant K, Gerin B, Chanteux H, Depelchin BO, Dhalluin S, Atienzar FA. 2012. Characterization of primary human hepatocytes, HepG2 cells, and HepaRG cells at the mRNA level and CYP activity in response to inducers and their predictivity for the detection of human hepatotoxins. Cell Biol Toxicol 28:69-87, DOI 10.1007/s10565-0119208-4.

Gitawati R. 2008. Interaksi obat dan beberapa implikasinya. Media Litbang Kesehatan 18(4):175-184.

Katzung BG. Farmakologi dasar dan klinik. Ed VIII. Diterjemahkan oleh Dripa Sjabana. Surabaya: Bagian Farmakologi Fakultas Kedokteran Universitas Airlangga; 2002. 
Matsuda H, Kinoshita K, Sumida A, Koichi Takahashi K, Fukuena S, Fukuda T, et al. 2002. Taurine modulates induction of cytochrome P450 3A4 mRNA by rifampicin in the HepG2 cell line. Biochimica et Biophysica Acta 1593: 93-98.

Sambrook J, Russel DW. Molecular cloning, a laboratory manual. Edisi III. New York: Cold Spring Harbor Laboratory Press; 2001: xxvi + $3.4-14.53+1.44$.

Yihai Wang, Limin Xiang, Chunhua Wang, Chao Tang, Xiangjiu He.Antidiabetic and antioxidant effects and phytochemicals of mulberry fruit (Morus alba L.) polyphenol enhanced extract. Plos One. 2013; 8(7): 1-10. 